\title{
REVIEW ARTICLE \\ PHYTOCHEMICAL AND ANTICANCER ACTIVITY OF AERIAL PARTS OF MORINGA OLEIFERA LAM
}

\author{
M. Shantha ${ }^{1}$, T. Ragupathi ${ }^{2} *$, B. Hasan Mohamed ${ }^{3}$, P. Maria Steffi ${ }^{4}$. \\ ${ }^{1}$ Department of pharmacognosy,Periyar College of Pharmaceutical Sciences, Tiruchirapalli- \\ 620021,Tamilnadu. \\ Shantha.cog@gmail.com \\ ${ }^{2}$ Department of pharmacognosy Shri Indra Ganesan Institute of Medical Science College of \\ Pharmacy, Manikandam, Tiruchirapalli-620012, Tamilnadu. \\ ragurms13@gmail.com \\ ${ }^{3}$ Department of pharmacognosy Shri Indra Ganesan Institute of Medical Science College of \\ Pharmacy, Manikandam, Tiruchirapalli- 620012, Tamilnadu. \\ ${ }^{4}$ Department of pharmacognosy Shri Indra Ganesan Institute of Medical Science College of \\ Pharmacy, Manikandam, Tiruchirapalli-620012, Tamilnadu.
}

\begin{abstract}
;
The aim of the present study was to find out anticancer property of Moringa oleifera lam of the family Moringacease populary called "MIRACLE TREE". Is a native of sub Himalayan tracts of Northern India and is widely cultivated in tropical and subtropical regions. Moringa is nature's medicine cabinet. It is best known as excellent source of nutrition and natural energy booster. The various parts of this plant such as the leaves, roots, seed, bark, fruit, flower and immature pods act as cardiac and circulatory stimulants, Anti-cancer, Anti-inflammatory, Anti-diuretic, Antiulcer, Anti-diabetic, Antibacterial are being employed for the treatment of different oilments in the indigenous system. Moringa oleifera is a multi-purpose herbal plant used as human food and an alternative medicinal purpose wordwide. Almost all parts from Moringa can be used as source and nutrition with other useful values
\end{abstract}

KEY WORDS: Moringa oleifera, leaf, Anticancer (Breast, Cervical), Cytotoxic, Phytochemical screening.

\section{INTRODUCTION}

Pharmacognostical studies on Moringa oleifera LAM, has begin early in 1950s which led to the discovery of anticancer and antibacterial pterygospermin in the plant. The plant kingdom represents a rich storehouse of organic compounds, many of which have been used for medicinal purposes and could serve as lead for the development of novel agents having good efficiency in various pathological disorder in the coming years. Moringa oleifera's traditional claims such as Anticancer, Anti-inflammatory, Antibacterial properties. The leaves are rich in iron and therefore high recommended for expectant mothers. The rich source of B-carotene, protein, vitamin-C, calcium and potassium and act as good source of natural antioxidants. In 
the presence of various types of antioxidant compounds such as ascorbic acid, flavonoids, phenolics, and carotenoids. The Moringa oleifera is used for Anticancer (breast cancer, cervical cancer), Anti- inflammatory, Anti-diabetic, Antimicrobial, Anti-hypertensive, Anti-ulcer, cholesterol lowering. The plants are used to treat lots of health problems like nervous disorder(such as muscle spasmodic, epilepsy, headache, hysteria) and also used for anemia, skin infections, blackheads, fever pain in joints, respiratory disorder, lactation hypertension and diabetes. Since all essential amino acids are present Moringa may be eightly called a complete food for total nutrition.

\section{Morphological Features:}

Moringa oleifera is fast -growing, deciduous tree. It can reach as hight of $10-12 \mathrm{~cm}(32-40)$ and the trunk, can reach a diameter of $45 \mathrm{~cm}(1.5 \mathrm{ft})$. The bark has a whitish-grey colour and is surrounded by thick cork. It is found wild and cultivated throughout the plains, especially in hedges and house yards, these under the tropical insular climate, and it plentiful near the sandy beeds and rivers. The flowers are about $1.0-1.5(112 \mathrm{~m})$, and long $2.0 \mathrm{~cm}(3 \backslash 4 \mathrm{~m})$ broad. It can grow well in the humid tropics or hot dry lands, can survive destitude solids and is little affected by drought. It tolerates a wide range of rainful with minimum annual rainful requirements estimated at $250 \mathrm{~mm}$ and a $\mathrm{pH}$ of 5.0-9.0. Materials and methods: Collection of plant material The leaves were collected from the Moringa oleifera from the Materials and methods: Collection of plant material The leaves were collected from the Moringa oleifera from the herbal garden. It was ensured that the plant was healthy and uninfected. The leaves were washed under running tap water to eliminate dust and other foreign particles and to cleanse the leaves thoroughly and dried.

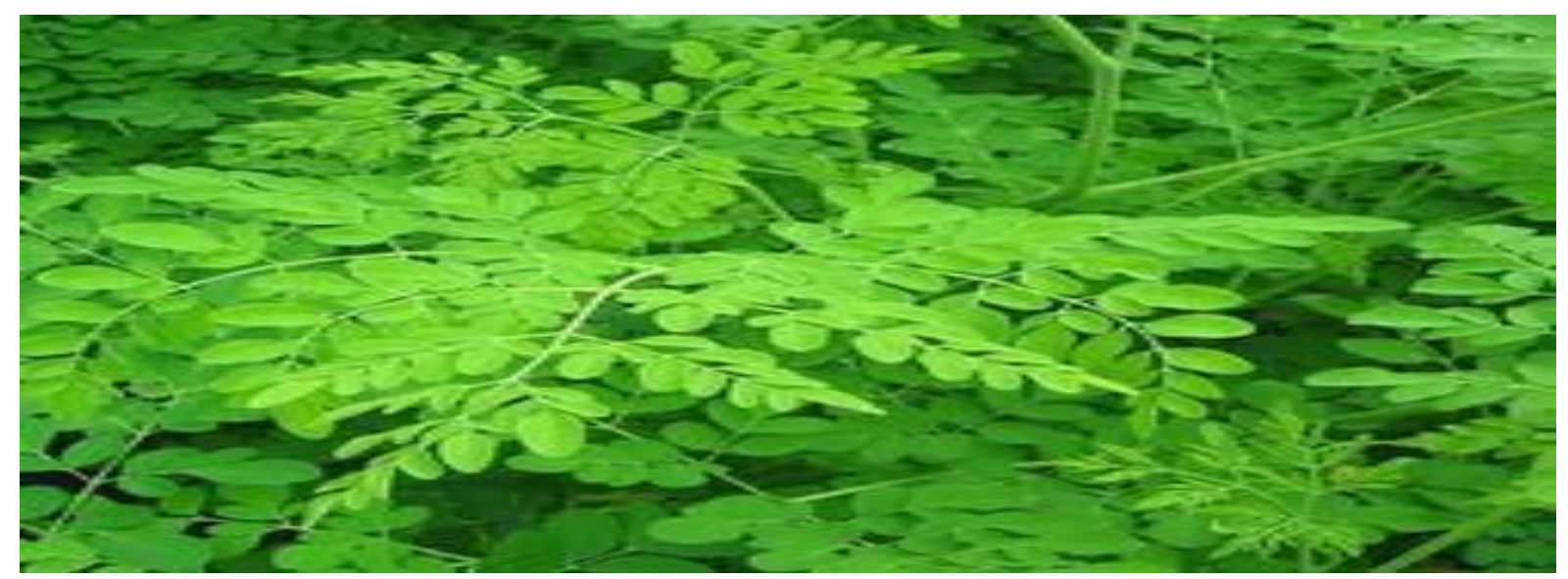




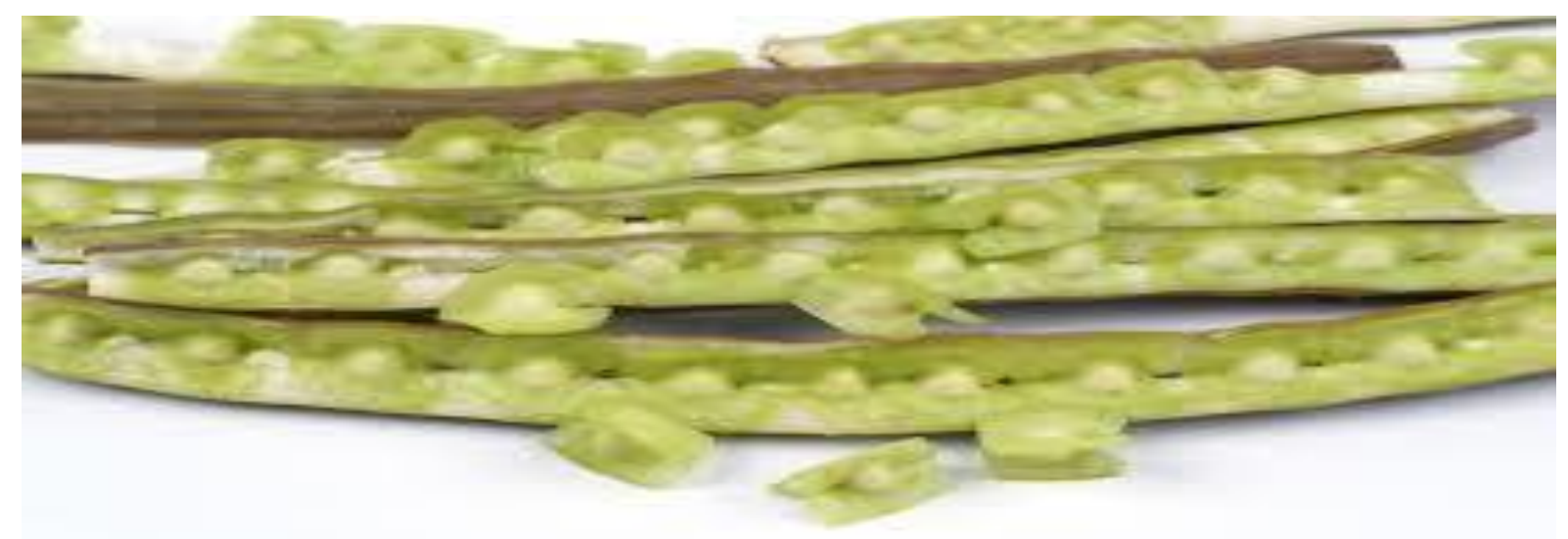

\section{Preparation of Leaf Extracts:}

Fresh leaves (20-30gm) of Moringa oleifera were shade dried at room temperature (32-35C) to constant weight over a period of 5 days. The dried leaves were ground into powdered using a mortar and pestle. $25 \mathrm{~g}$ of the powdered leaves were separately extracted in $500 \mathrm{ml}$ conical flask with $90 \%$ ethanol and water. The conical flask were plugged with rubber corks, then shaken at 120rpm for $30 \mathrm{~min}$ and allowed to stand at room temperature for 5 days with occasional manual agitation of the flask using a sterile glass rod at every 24hour. The extracts were separately filtered using sterile Whatman no1. Filter paper.

\section{Nutritional Analysis:}

Moringa leaves are extenly nutritions. In fact they contain larger amounts of several nutritions than common food often associated with these nutrients. These include vitamin $\mathrm{C}$, which fights a host of illness including colds and flu: vitamin A, which act as a shield against eye disease, skin disease, heart disease, diarrhea and many other disease, and the high source of calcium, B-carotene, potassium as well as protein. Due to presence of several rots of antioxidant compounds such as flavonoids, phenolics, calcium, iron ascorbic acid, and carotenoids, which builds strong bones and teeth and helps, of prevent osteopososis.

\section{ANTI-CANCER}

Moringa is revealed to possess potential therapeutic effects to fight cancer, has been recognised by folk medicine practitions as it has antitumor, propertiesl and cancer prevention potential. Are few isolated bioactive compounds from the seeds were tested for antitumor promoting activity using 7,12dimethylbenzanthracene (DMBA) as initiator and 12-otetradecanoylphorbol-13-acetate (TBA) as tumor promoter and the anticancer prevent. The present study aimed to assess the cytotoxic effect of moringa oleifera plant leaf extracts on three different cell lines (MCF-7, MDA-MB-468 and MDA-MB231). Different doses of plant extract and standard were taken and introduced into cancer cell lines were recorded at $72 \mathrm{hrs}$ respectively it clearly showed by effect cell growth inhibition. Moringa oleifera leaves extracts found in the indigenous environment as an anti-cancer agent. In the presence of fatty acids could have attributed to the chemopreventive effect of bMO which modulates apoptosis in 
colon carcinogenesis. The impact of Moringa extracts on different cancer cell lines was investigated showing that Moringa root core were shown in table No. 1.

\section{Breast Cancer}

These are few of medicinal plants were used for treatment of breast cancer have been documented. The present aimed to assess the cytotoxic effect of moringa oleifera plant leaf extracts on three different cell lines (MCF7, MDA-MB-468 and MDA-MB-231). Different doses of plant extract and standard were taken and introduced into cancer cell lines were recorded at $72 \mathrm{hrs}$ respectively it clearly showed by effect cell growth inhibition of human breast cancer cell lines MCF-7, MDA-MB-468 and MDA-MB-231) in dose and specific time duration for inhibition of cell. M.oleifera leaf extracts have antiproliferative and pro-apoptotic effects on the breast cancer cell lines in a concerntration and time depent manner, which suggested their potential to be used as a therapeutic strategy for breast cancer.

\section{Cervical (UTERUS) Cancer}

The leaves of Moringa oleifera were tested for their anti cancer effects in combination with oncolytic vesicular stomatitis (VSV).The ethanolic extract of Moringa oleifera was effective inhibiting proliferication of cervical cancer. The combination of oncolytic viral therapy with Moringa oleifera represents an alternative therapeutic option for the treatment of cervical cancer.

\section{ANTI- INFLAMMATORY}

The crude ethanolic extract of dried seeds was tested for anti-inflammatory activity using carrageenan induced inflammation in the paw of mice by various workers and found to inhibit $85 \%$ of inflammation at a dose of $3 \mathrm{mg} \mathrm{kg}$ body weight, while the nature green seeds inhibited edema by $77 \%$ at the same dose. Hot water infusion of flowers, leaves, seeds also showed antiinflammatory activity against carrageenan induced hind paw edema and its were shown in table No. 2.

\section{ANTI ULCER}

The methanol fraction of M. Oleifera leaf extract showed antiulcerogenic and hepatoprotective effects in rats. Aqeuous leaf extract also showed antiulcer effect indicating that the antiulcer component is widely distributed in this plant. Moringa roots have also been reported to possess hepatoprotective effect which may be due to the presence of quercetin awell known flavonoid with hepatoprotective activity and shown in table No. 3.

\section{EYE INFECTION}

Through there are many causes of blindness vitamin A, deficiency causes impaired dark adaption and night blindness. Eating Moringa leaves, pods and leaf powder which contain high proportion of vitamin A can help to prevent night blindness and eye problem in children. Ingesting drumstick leaves (B -carotene and leutin) with oil helps in improving vitamin A nutrition and prehaps delays the onset of cataract. Also the juice can be instilled into eyes in cases of conjunctivitis. 


\section{CARDIAC AND CIRCULATORY STIMULANT}

All parts of the tree are reported to be used as cardiac and circulatory stimulant. Moringinine acts on the sympathetic nervous system and act as a cardiac stimulant.

Table No. 1 The Leaves Extracts of Moringa oleifera Lam.

\begin{tabular}{|l|l|l|l|l|l|l|l|l|}
\hline No & Bioactivity & Test cell & \multicolumn{2}{|c|}{$\begin{array}{l}\text { Parameters } \\
\text { tests }\end{array}$} & \multicolumn{3}{|c|}{ Activity of extracts } & Comments \\
\cline { 4 - 7 } & & & AQ & EH & MH & AC & \\
\hline 1. & Anti-cancer & $\begin{array}{l}\text { PC3 Cell } \\
\text { lines }\end{array}$ & $\begin{array}{l}\text { In silico } \\
\text { docking of } \\
\text { ligands }\end{array}$ & & H12 & & $\begin{array}{l}\text { Studies are } \\
\text { few but } \\
\text { promising }\end{array}$ \\
& & & $\begin{array}{l}\text { Cancer cell } \\
\text { growth } \\
\text { inhibition }\end{array}$ & & & H42 & & \\
\hline
\end{tabular}

Table No. 2 The Ethanolic Extracts of Dried Seeds of Moringa oleifera Lam.

\begin{tabular}{|c|c|c|c|c|c|c|c|c|}
\hline \multirow[t]{2}{*}{ No } & \multirow[t]{2}{*}{ Bioactivity } & \multirow[t]{2}{*}{ Test cell } & \multirow{2}{*}{$\begin{array}{c}\text { Parameters } \\
\text { tests }\end{array}$} & \multicolumn{4}{|c|}{ Activity of extracts } & \multirow[t]{2}{*}{ Comments } \\
\hline & & & & $\mathrm{AQ}$ & EH & $\mathrm{MH}$ & $\mathrm{AC}$ & \\
\hline \multirow[t]{5}{*}{1.} & $\begin{array}{l}\text { Anti } \\
\text { inflammatory }\end{array}$ & RAW264.7 & $\begin{array}{l}\text { Inhibition of } \\
\text { IFM } \\
\text { mediators }\end{array}$ & & $\mathrm{H} 25$ & & & \multirow{5}{*}{$\begin{array}{l}\text { Involment } \\
\text { of } \mathrm{NF}-\mathrm{KB} \\
\text { path way is } \\
\text { confirmed. }\end{array}$} \\
\hline & & & $\begin{array}{l}\text { Inhibition of } \\
\text { proIFM } \\
\text { cytokiness }\end{array}$ & & $\mathrm{H} 25$ & & & \\
\hline & & & $\begin{array}{l}\text { Inhibition of } \\
\text { antiIFM } \\
\text { cytokiness }\end{array}$ & & $\mathrm{H} 25$ & & & \\
\hline & & & $\begin{array}{l}\text { Protein } \\
\text { denaturation }\end{array}$ & & $\mathrm{H} 47$ & & & \\
\hline & & & $\begin{array}{l}\text { Inhibition of } \\
\text { edema }\end{array}$ & L49 & & & & \\
\hline
\end{tabular}


Table No. 3 The Methanol Extracts of Leaves of Moringa oleifera Lam.

\begin{tabular}{|l|l|l|l|l|l|l|l|}
\hline No & Bioactivity & Test cell & $\begin{array}{l}\text { Parameters } \\
\text { tests }\end{array}$ & \multicolumn{4}{|c|}{ Activity of extracts } \\
\cline { 5 - 7 } & & AQ & EH & MH & AC \\
\hline Anti ulcer & $\begin{array}{l}\text { Aspirin } \\
\text { ulcers in } \\
\text { rats }\end{array}$ & $\begin{array}{l}\text { Decrease in } \\
\text { ulcer index }\end{array}$ & & & L54 & \\
\hline
\end{tabular}

\section{CONCLUSION}

The multiple benefits of Moringa oleifera made it a true miracle of nature. Moringa extracts on different cancer cell lines was investigatedthe root core. These findings suggested the leaf extreacts of moringa collected from the widely distributed in different India region possess anti-cancer activity that can be used to develop new drugs for treatment. Numerous studies have been conducted to the plants not yet developed as a drug by pharmaceutical industries.

\section{ACKNOWLEDGEMENT}

I express my heartful aand profound thanks to our honorable management of Shri Indra Ganesan Institute of medical science college of pharmacy. Manikandam,Tiruchirapalli 620012,TamilNadu.

\section{REFERENCES}

[1] Durgesh KD, Jyotsna D, Anil K, Ratan KG. A multipurpose tree-Moringa oleifera. Int J Pharm Chem Sci. (2013) 41523.

[2] Anwar F, Latif S, Ashraf M, Gilani AH. Moringa oleifera: A food plant with multiple medicinal uses. Phytother Res. (2007) 17-25.

[3] Bhattacharya A, Naik MR, Agrawal D, Rath K, Kumar S, Mishra SS. Anti-pyretic, antiinflammatory, and analgesic effects of leaf extract of drumstick tree. J Young Pharm. (2014) 61-5.

[5.] Awanish P, Rishabh DP, Poonam TP, Gupta JH, Saumya BA. Moringa oleifera Lam. (Sahijan) - a plant with a plethora of diverse. Therapeutic benefits: an updated retrospection. Med Arom Plants. (2012) 1-8. [Google Scholar]

[6] Amrutia JN, Lala M, Srinivasa U, Shabaraya AR, Semuel MR. Anticonvulsant activity of Moringa oleifera leaf. Int Res J Pharm. (2011) 160-2.

[7] Mehta J, Shukla A, Bukhariya V, Charde R. The magic remedy of Moringa oleifera: an overview. Int J Biomed Adv Res. (2011) 215-27.

[8] Ndiaye M, Dieye AM, Mariko F, Tall A, Sall Diallo A, Faye B. [Contribution to the study of the anti-inflammatory activity of Moringa oleifera (Moringaceae)] Dakar Med. (2002) 210 2.

[9] Saini RK, Shetty NP, Giridhar P. Carotenoid content in vegetative and reproductive parts of commercially grown Moringa oleifera Lam. cultivars from India by LC-APCI-MS. Eur Food Res Technol. (2014) 971-8. 
[10] Saini RK, Shetty NP, Prakash M, Giridhar P. Effect of dehydration methods on retention of carotenoids, tocopherols, ascorbic acid and antioxidant activity in Moringa oleifera leaves and preparation of a RTE product. J Food Sci Technol. (2014) 2176-82.

[11] Amaglo NK, Bennett RN, Lo Curto RB, Rosa EAS, Lo Turco V, Giuffrida A, et al. Profiling selected phytochemicals and nutrients in different tissues of the multipurpose tree Moringa oleifera L. grown in Ghana. Food Chem. (2010) 1047- 54.

[12] Coppin JP, Xu Y, Chen H, Pan MH, Ho CT, Juliani R, et al. Determination of flavonoids by LC/MS and anti-inflammatory activity in Moringa oleifera. J Funct Foods. (2013) 1892-9

13. Saini RK, Manoj P, Shetty NP, Srinivasan K, Giridhar P. Relative bioavailability of folate from the traditional food plant Moringa oleifera L. as evaluated in a rat model. $j$ Food Sci Technol. (2016) 511-20.

[14] Saini RK, Shetty NP, Giridhar P. GC-FID/MS analysis of fatty acids in Indian cultivars of Moringa oleifera: potential sources of PUFA. J Am Oil Chem Soc. (2014) 1029-34.

[15] Saini RK, Manoj P, Shetty NP, Srinivasan K, Giridhar P. Dietary iron supplements and Moringa oleifera leaves influence the liver hepcidin messenger RNA expression and biochemical indices of iron status in rats. Nutr Res. (2014) 630- 8.

[16] Bhattacharya A, Ghosh G, Agrawal D, Sahu PK, Kumar S, Mishra SS. GC-MS profiling of ethanolic extract of Moringa oleifera leaf. Int J Pharm Bio Sci.( 2014) 263-75.

[17] Bennett RN, Mellon FA, Foidl N, Pratt JH, Dupont MS, Perkins L, et al. Profiling glucosinolates and phenolics in vegetative and reproductive tissues of the multi-purpose trees Moringa oleifera L. (horseradish tree) and Moringa stenopetala L. J Agric Food Chem. (2003) 3546-53.

[18] Nwosu MO, Okafor JI. Preliminary studies of the antifungal activities of some medicinal plants against Basidiobolus and some other pathogenic fungi. Mycoses. (1995) 191-5.

[19] Kerharo PJ. Un remede popularized Sengalais: le 'Nebreday' (Moringa oleifera lann. employs therapeutiques en milieu Africain chimie et pharmacologie. Plantes Med Phytother. (1969) 219. 